\title{
Poemas sobre São Paulo
}

VÁRIOS AUTORES

CEMITÉRIO DO ARAÇÁ

Quando ainda era menino, voltava calado para casa, interrogava teu muro alto. Eras o melhor vizinho.

Habituado a jogar futebol na sinuosa rua dos fundos, estranhava que as bolas não voltassem do teu mundo.

Você resistiu ao cerco da cidade que cresceu (eu também cresci) sempre à tua volta.

Repisando nosso passado, hoje, finalmente, te visito. Busco meu pai enterrado dentro do teu labirinto.

Augusto Massi 
nascida

na beira do pântano, no meio

de gente rude, criada

para dar nome

às cabras

e cultivar terras inóspitas

daí, dizem

os filólogos, tantas metáforas

agrárias, nesta língua

em que uma página

antes de ser

página do livro que estou lendo

serão estacas

fincadas na terra

- entre elas se espalham

as ramas da parreira

língua em que feliz

é a árvore que produz; caduco

o fruto que cai; delírio se diz

do grão que brota

fora do sulco

(isto é, da lira

pois esse é o nome da linha

do rego

da vala

rasgada no chão

para o germinar das sementes)

língua que, como diz

um eminente linguista português, seguiria ordenando guerras e colheitas

não tivesse ela própria

"cindido-se desvairadamente"

em cabos

rocas

oceanos inteiros 
a ponto de parir toda uma geografia

e florescer no extremo do extremo

a ponto de florescer aqui

neste trem

nesta janela

junto às águas negras

do pinheiros

(água que me fala

tão de perto, rente à pele

dos ouvidos, fragmento

de conversa, soluço

entrecortado de trilhos

"eu me viro, eu me viro")

enquanto

a caminho de casa

folheio as páginas de um livro

SOBRE A HISTÓRIA DA LÍNGUA PORTUGUESA

e volta e meia, entre uma

linha e outra, estico os olhos

pelos companheiros de viagem

neste expresso metropolitano -

gente de todo tipo, corpo, cara, tamanho

que porta consigo seus problemas \&

pacotes de fim de ano -

e leio, em cada um, o transeunte

de uma língua

em busca de seu destino

- cidade universitária jaguaré presidente altino -

transeunte como eu

prestes a descer

em qualquer ponto do caminho

até que num repente

a noite salta da outra margem

desliza sobre a água, entra pela porta

enquanto - sem tempo de fechar o livro 
"cuidado com o vão

entre o trem e a plataforma"

eu piso

sem volta

do lado de fora

Alberto Martins

(Inéditos) 
Começa na Praça da República

de maneira desde já oblíqua e ambígua

e vai pondo árvores abstratas

em seu caminho.

Passantes passam-lhe ao longo

e ao estreito, conhecidos meliantes

e mundanas

líricas sem escamas e sem dentes

ou de sorriso afiado como um corte,

professores de medo em uniformes

de um azul mais escuro do que o preto

da noite que dissolve esses contornos

e marginais possíveis,

impossíveis trazendo a punição na testa

como um emblema.

O uivo dolorido da polícia

estilhaça o sono nas calçadas.

A culpa pula, esconde-se na esquina,

espreita atrás do cartaz,

dá boa-noite e vai punir-se

no porão do edifício, perplexa.

A rua que se afina segue os fios

do ônibus elétrico:

transatlântico salão iluminado deslizante

caixão claro vazio baleia oca sob

a luz corrompida da lua. A rua

transporta para o lado das Perdizes,

Pacaembu, Lapa, Arvoredo, Tempo

os veículos que analisa, canaliza,

o imaginário corredor que é o ônibus

de olhares furados.

Enquanto, maliciosa, pisca a análise,

a rua calada e fria mais que a lua

vai derivando tudo para o lado

do longe e para ele ela deriva

seu

sempre

que é simplesmente um nunca. 
Rubens Rodrigues Torres Filbo

(Novolume. São Paulo: Iluminuras, 1997. p.77) 


\section{SEGUNDO PAPEL}

a cidade é o óbvio, o que salta aos olhos ulula, o que brilha e fede

a cidade é o cais caos sob controle outro dia de luto, de luta, de luxo

a cidade é perder outro sol que agride outra lua (a cidade comporta), mesma via

e é sempre tarde e o lugar que falta e o que nos prende, perene, perece

\section{Tarso de Melo}

(Planos de fuga e outros poemas. São Paulo: Cosac Naify; Rio de Janeiro: Viveiros de Castro Editora, 2005. p.70) 
O VENTO NESSA CIDADE

$\mathrm{O}$ vento nessa cidade

vem sempre na mão contrária.

Fumaça, papéis e poeira

pegam carona, sem rumo

(pessoas também, se bem que elas

não se diferenciam muito

de papéis, poeira ou fumaça). $\mathrm{O}$

preto, que à mão só tem dedos,

grava na sarjeta o mapa

de seu tesouro escondido,

já são vistos traços brancos,

mas vamos de olhos cerrados,

pois nessa cidade o vento

não aceita ser contestado.

Paulo Ferraz

(Evidências pedestres. São Paulo: Selo Sebastião Grifo, 2007. p.14) 
ÀS MINHAS COSTAS

As portas do metrô mastigam

$\mathrm{o}$ ar condicionado.

Estou em trânsito, com os demais.

Percorremos a rede incorpórea

que há de permanecer.

Não se ultrapassa a linha amarela.

Nada cheira. E a escada rolante

- áspera via - até se alegoriza

ao conduzir-nos de volta ao simulacro

passageiro das avenidas.

Na saída, ponho os óculos escuros.

\section{Sérgio Alcides}

( $O$ ar das cidades: poemas (1996-2000). São Paulo: Nankin, 2000. p.33) 


\section{A CIDADE}

Por mais que insistas em recusar, esta é, sim, a tua cidade concreta onde tantos te ofereceram amizade e o amigo partiu pela porta secreta.

Andaste cabisbaixo pelas calçadas remoendo as humilhações do trabalho. Marcaste este chão com teus passos, dores recolhidas como um rebotalho.

Aqui nasceram os filhos, a epifania das infâncias que sumiram passageiras. Abriste envelopes com muito medo, receoso daquelas notícias derradeiras.

Tu que amas a simetria permanente viste a barriga da cidade arregaçada. Como nas telas de Anselm Kiefer, tens nela tuas perplexidades retratadas.

\section{Donizete Galvão}

(O homem inacabado. São Paulo: Portal, 2010. p.59) 


\section{TRENS URBANOS}

Não são como os ratos

ou os vira-latas.

Nunca desviam, os trens.

Este sempre acompanha o rio morto vivo.

Aqui dentro, uns lutam pra dormir, outros, pra acordar.

Uns achando que a vida é preparação pra morte.

Outros, que a morte é o motor da vida.

Outros não acham nada. Sobrevivem.

Os meus botões pensam:

morte em vida é que é problema.

Cocteau pensava além: a vida

é uma queda na horizontal.

O trem para. A porta se abre.

Na falta,

qualquer rua, pra mim, é rio.

Ruy Proença

(Visão do térreo. São Paulo: Editora 34, 2007. p.41) 


\section{Créditos dos poetas}

Augusto Massi, como poeta, publicou Negativo (Companhia das Letras, 1991) e A vida errada (7Letras, 2001).

Alberto Martins é autor dos livros Uma noite em cinco atos (Editora 34, 2009) e Em trânsito (Companhia das Letras, 2010).

Rubens Rodrigues Torres Filho publicou Poros (Livraria Duas Cidades, 1989), Retrovar (Iluminuras, 1993) e Novolume (Iluminuras, 1997), entre outros.

Tarso de Melo é autor de Planos de fuga e outros poemas (São Paulo: Cosac Naify; Rio de Janeiro: Viveiros de Castro Editora, 2005), Lugar algum: com uma teoria da poesia (Alpharrabio, 2007) e Exames de rotina (Editora da Casa, 2008), entre outros.

Paulo Ferraz publicou, sob o Selo Sebastião Grifo, os livros Constatação do óbvio (1999), Evidências Pedestres e Do novo nada, ambos em 2007.

Sérgio Alcides escreveu o livro de poesias Nada a ver com a lua (Sette Letras, 1996) e $O$ ar das cidades: poemas (1996-2000) (Nankin Editorial, 2000).

Donizete Galvão publicou, em 1988, Azul navalha (T. A. Queiroz Editor), em 1999, Ruminações (Nankin Editorial) e, em 2010, O homem inacabado (Portal Editora), entre outros.

Ruy Proença é autor dos livros de poesias Pequenos Séculos (Klaxon, 1985), A lua investirá com seus chifres (Giordano, 1996) e Visão do térreo (Editora 34, 2007), entre outros. 